\title{
Factors associated with stunted growth in children below 11 years of age in Antioquia, Colombia, 2004
}

\author{
Bibiana Andrea Castro, MSc ${ }^{1}$, Edwin Rolando González, MPH, MSc ${ }^{2}$, \\ Marta Cecilia Álvarez, MSc ${ }^{3}$, Angela María Segura, PhD ${ }^{4}$
}

\section{SUMMARY}

Objective: To explore some factors associated to stunted growth in children below 11 years of age in the Department of Antioquia.

Methodology: Cross-sectional study using the databases of alimentary and nutritional profiles in homes of Antioquia in 2004 , based on a representative random sample of homes in the department (95\% reliability and error margin of $3 \%)$. For this study, $100 \%$ of the records of children below 11 years of age were used. A model of generalized equations estimation was constructed for stunted growth classified by a $Z$ score smaller than -2 standard deviation with respect to $\mathrm{p} 50$ of the $1978 \mathrm{NCHS}$ (Centro Nacional de Estadísticas de la Salud - National Center for Health Statistics). Data were analyzed using the GLIMMIX Procedure: SAS version 9.1.

Results: We found $18.6 \%$ of the children with stunted growth, $75 \%$ of the homes with male head of household, $70 \%$ of heads of household with maximum 5 years of schooling; $47 \%$ of homes were nucleated bi-parental, and $40 \%$ extensive with a 5 -member median per home; $56.4 \%$ poor per unsatisfied basic needs, and $80 \%$ in alimentary insecurity. The factors associated to stunted growth were: female gender, 1-5 years of age, head of household with less than 6 years of schooling, more than 5 people in the home, more than two household members under 7 years of age, coming from a poor home per unsatisfied basic needs, belonging to a sub-region different from Medellin, food availability of less than 30 different foods per week, no production of food, and head of household under 40 years of age.

Conclusions: Herein, we show evidence of the magnitude of poverty and association of precarious socioeconomic conditions with stunted growth in Antioquia. The study shows the importance of considering the correlated nature of the data for the construction of the model.

Keywords: Children; Malnutrition; Poverty; Social inequity; Alimentary security; Antioquia; Colombia.

Colomb Med. 2011; 42: 207-14

Factores asociados con el retraso del crecimiento en menores de 11 años en Antioquia, Colombia, 2004

\section{RESUMEN}

Objetivo: Explorar algunos factores asociados con el retraso del crecimiento en menores de 11 años en Antioquia, Colombia.

Metodología: Estudio de corte transversal utilizando las bases de datos del perfil alimentario y nutricional de los hogares de Antioquia en el año 2004. Muestra representativa aleatoria de hogares por subregión del departamento (95\% de confianza y error del 3\%). Se tomó 100\% de los registros de los menores de 11 años. Se construyó un modelo de estimación de ecuaciones generalizadas para el retraso del crecimiento clasificado por puntaje $\mathrm{Z}$ menor de -2 desviaciones estándar, con respecto al p 50 de la NCHS (Centro Nacional de Estadísticas de la Salud) 1978. Los datos se analizaron usando el procedimiento GLIMMIX: SAS versión 9.1.

1. Research Direction Assistant, Universidad CES, Medellín, Colombia. e-mail: bcastro@ces.edu.co

2. Professor, National Faculty of Public Health, Universidad de Antioquia, Medellín, Colombia. e-mail: edwin@saludpublica.udea.edu.co

3. Professor, School of Nutrition and Dietetics, Universidad de Antioquia, Medellín, Colombia. e-mail: mcalvarez@une.net.co

4. Professor, Faculty of Medicine, Universidad CES, Medellín, Colombia. e-mail: asegura@ces.edu.co Received for publication February 4, 2010 Accepted for publication April 13, 2010 
Resultados: Del total de niños, $18.6 \%$ tenían retraso del crecimiento, $75 \%$ de hogares con jefatura masculina, $70 \%$ de jefes con máximo 5 años de escolaridad; $47 \%$ de hogares nucleados biparental y $40 \%$ extensos, mediana de 5 integrantes por hogar; $56.4 \%$ pobres por necesidades básicas insatisfechas y $80 \%$ en inseguridad alimentaria. Los factores asociados con el retraso del crecimiento fueron: sexo femenino, edad entre 1 y 5 años, jefe con escolaridad menor de 6 años, más de 5 personas en el hogar, más de dos menores de 7 años en el hogar, provenir de un hogar pobre por necesidades básicas insatisfechas, pertenecer a una subregión diferente a Medellín, disponibilidad menor a 30 alimentos diferentes por semana, no producir alimentos y jefe de hogar menor de 40 años.

Conclusiones: Se evidenció la magnitud de la pobreza y la asociación de condiciones socioeconómicas precarias con el retraso del crecimiento en Antioquia. Se demostró la importancia de considerar la naturaleza correlacionada de los datos para la construcción del modelo.

\section{Palabras clave: Niños; Desnutrición; Pobreza; Inequidad social; Seguridad alimentaria; Antioquia; Colombia.}

\section{Colomb Med. 2011; 42: 207-14}

The dietary and nutritional improvement program in Antioquia(MANA, Governor's office of Antioquia)along with Universidad de Antioquia elaborated a descriptive study in 2004 to obtain the dietary and nutritional profile of homes in the department ${ }^{1}$. In this study, it was found that the most affected anthropometric indicator in children below 11 years of age corresponded to height for age. Additionally, for the year before the study, malnutrition was the main cause of mortality in children from 1 to 4 years of age and in children under one year of age, malnutrition was among the first 5 causes of mortality.

Hence, and given the availability of the dietary and nutritional profile done, it was necessary to advance on the explicative processes to explain the phenomenon of malnutrition in the department, evidencing its magnitude and determining the most important factors associated to the problem. Thus, this study seeks to determine demographic, socioeconomic, and dietary factors that explain stunted growth in children below 11 years of age in homes from different regions of Antioquia for 2004. Likewise, we expect this information becomes useful knowledge in decision making, and in this sense, in guiding public policy.

\section{MATERIALS AND METHODS}

Type of study. A transverse study was performed based on secondary sources using records from the data base in the project on «Dietary and nutritional profile in homes from the department of Antioquia» ${ }^{1}$.

Sampling. The data base contained 3240 records of children below 11 years of age from 1658 homes distributes in the 9 sub-regions of the department of Antioquia and the city of Medellín, Colombia. Of the total number of records, 273 did not have information on height and/or age of the minors, which was indispensable to determine the nutritional state, therefore, these were excluded. After the exclusion of these data, there were 2967 records left of children from 1581 homes.

Given that the samples from the previous study were random and representative of homes per region in the department and that all the household members were surveyed, we verified if the number of records per region was close to the sample size that would have been required to study stunted growth in each subregion. For this purpose, we used the formula for a proportion in finite population with a confidence level of $1-\mathrm{a}=95 \%$ and $5 \%$ error. The formula for finite population was considered because the population of children below 11 years of age per sub-regions for 2004 was known.

According to results obtained, it was concluded that in all sub-regions the number of records from the data base was greater than the simple size required; thereby, the data permit approaching the prevalence of stunted growth per sub-regions in the department.

Variables. The dependent variable was the stunted growth, for this we used the $z$ score from the NCHS/ OMS reference norm ${ }^{2}$. The independent variables were demographic, socioeconomic, and dietary in nature.

Statistical methods. Bearing in mind that the children's records were grouped by municipalities and that these are in turn within the sub-regions, we sought to construct a mixed generalized linear model. It was considered mixed because it contained fixed effects (sub-region) and random effects (municipalities). The model mentioned yielded an estimate of zero for the variation of the children in the municipalities; for this reason the consideration of the municipality level within the model was discarded.

After discarding the municipality level, a standard 
logistic regression and a model of generalized equation estimation (GEE) were run. The latter model considered the nested structure of the children's data within the sub-regions. To define which of the two models presented a better adjustment, a comparison was made through the Akaike information criterion. According to this criterion, we selected the model showing the lowest Akaike score. The statistic values for the two models were: Standard logistic regression: 15844.43, GEE Model: 14787.60. This said, it was concluded that the most suitable model was the one bearing in mind the nested structure of the data (GEE).

Analysis. The univariate analysis used frequencies, percentages, and descriptive statistics; the bivariate analysis used statistical significance tests via Fisher's exact test, and the Odds Ratio (OR) was calculated along with its respective confidence intervals (CI). For the multivariate analysis, a GEE model was run by using the backward procedure.

Data processing. Done on SPSS version 11.5 and SAS version 9.1 GLIMMIX Procedure.

Limitations of the study. The previous research did not inquire on the health status of the children, especially that related to respiratory infection and diarrhea, which are variables that have been reported in literature as associated to the phenomenon. Likewise, although stunted growth is frequently used as proxy of chronic malnutrition, there are medical conditions affecting height and which were not inquired, such as endocrine and/or genetic disease.

Ethical considerations. According to article 11 of resolution $\mathrm{N}^{\circ} 008430$ of 4 October 1993 by the Ministerio de Salud de Colombia (Colombian Health Ministry), the current research was considered risk free given that it was based on secondary information sources and there was no direct contact with the individuals studied. The data base was only used for the objectives stated in the research and theidentities of those registered therein were never divulged. Also, the use of the data bases was authorized by the institutions participating in the initial study.

\section{RESULTS}

Description of the population studied. We analyzed the records of 2967 children below 11 years of age located in 1581 homes from the nine sub-regions of
Antioquia and the city of Medellín.

Demographic characteristics. Regarding the gender of the children below 11 years of age, a similar proportion of boys and girls were found. The average age of the boys was 5 years with a standard deviation of 3.1 years. Regarding the gender of the heads of the households, it was determined that there is predominance of male heads of household (75.1\%). The ages of the heads of household ranged between 15 and 89 years of age, with an average of 43.2 years and a standard deviation of 13.6 years. The years of schooling ranged between 0 and 18 years, with an average of 4.5 years and a standard deviation of 3.7 years.

Socioeconomic characteristics. In reference to the place of residence of the minors, there were similar proportions of urban and rural homes. Most of the homes of the children in the study (87.2\%) were classified into two groups according to the typology of the home: $47.2 \%$ lived in nucleated homes with both parents and $40 \%$ came from extensive homes. The number of individuals in the home ranged from 2 to 14 people, with an average of 5 people and a standard deviation of 2 people. Regarding the number of children below 7 years of age, the homes had between 0 and 6 children within this age range, with an average of 1.3 children and a standard deviation of 1 child. According to the indicator of unsatisfied basic needs (UBN), it was found that $43.6 \%$ of the homes of the minors were poor and among these, $12.8 \%$ were under conditions of misery.

Nutritional and dietary characteristics. An 18.6\% prevalence of stunted growth was found. The number of different foods available for a week ranged between 1 and 87 , with an average of 31.8 food items/week and a standard deviation of 13.3 food items/week. Some $53.3 \%$ of the homes were under energetic insufficiency, indicating that the availability per capita of calories/ day was lower than the recommended amount. A total of $78 \%$ of the homes were perceived under dietary insecurity. With respect to the production of foods from a crop or animal breeding, it was determined that $40.5 \%$ of the homes reported the production of food.

Exploration of the association between stunted growth and demographic, socioeconomic, and feeding variables. Upon analyzing the behavior of stunted growth in the different sub-regions of Antioquia, it was determined that Bajo Cauca, North, and Urabá were 
Table 1

Distribution of stunted growth according to demographic characteristics of children below 11 years of age and their homes. Antioquia, 2004

\begin{tabular}{|c|c|c|c|c|c|c|c|}
\hline \multirow[t]{2}{*}{ Variable } & \multirow[t]{2}{*}{ Category } & \multicolumn{2}{|c|}{ Stunted growth } & \multirow{2}{*}{$\begin{array}{c}\% \text { of Stunted } \\
\text { growth }\end{array}$} & \multirow[t]{2}{*}{$\mathbf{F}$} & \multirow[t]{2}{*}{ p } & \multirow[t]{2}{*}{ OR (Cl 95\%) } \\
\hline & & Yes & No & & & & \\
\hline \multirow[t]{10}{*}{ Sub-region } & Valle de Aburrá & 31 & 216 & 12.6 & 5.6 & $0.0001^{b}$ & $1.09(0.63-1.87)$ \\
\hline & East & 47 & 222 & 17.5 & & & $1.61(0.97-2.65)$ \\
\hline & Southeast & 36 & 222 & 14.0 & & & $1.23(0.73-2.01)$ \\
\hline & West & 40 & 203 & 16.5 & & & $1.50(0.89-2.50)$ \\
\hline & North & 81 & 284 & 22.2 & & & $2.16(1.37-3.43)$ \\
\hline & Northeast & 49 & 208 & 19.1 & & & $1.79(1.09-2.94)$ \\
\hline & Magdalena Medio & 38 & 234 & 14.0 & & & $1.23(0.73-2.07)$ \\
\hline & Urabá & 80 & 297 & 21.2 & & & $2.04(1.29-3.24)$ \\
\hline & Bajo Cauca & 120 & 310 & 27.9 & & & $2.94(1.89-4.57)$ \\
\hline & Medellína & 29 & 220 & 11.6 & & & 1 \\
\hline \multirow[t]{2}{*}{ Sex of child } & Male $^{\mathrm{a}}$ & 235 & 1267 & 15.6 & 21.26 & $0.0001^{b}$ & $1.57(1.30-1.91)$ \\
\hline & Female & 316 & 1149 & 21.6 & & & \\
\hline \multirow[t]{3}{*}{ Age of the child } & $<1^{\mathrm{a}}$ & 27 & 236 & 10.3 & 6.13 & $0.0022^{b}$ & 1 \\
\hline & $1-5$ & 273 & 1090 & 20.0 & & & $2.13(1.39-325)$ \\
\hline & $6-10$ & 251 & 1090 & 18.7 & & & $1.97(1.29-3.01)$ \\
\hline \multirow{5}{*}{$\begin{array}{l}\text { Sex of head } \\
\text { of household } \\
\text { Age of head } \\
\text { of household }\end{array}$} & Male $^{a}$ & 407 & 1809 & 18.4 & 0.49 & 0.4836 & $1.08(0.87-1.34)$ \\
\hline & Female & 144 & 607 & 19.2 & & & \\
\hline & $<30$ & 106 & 383 & 21.7 & 3.94 & $0.0196^{b}$ & $1.38(1.06-1.78)$ \\
\hline & $30-39$ & 184 & 737 & 20.0 & & & $1.27(1.02-1.57)$ \\
\hline & $>39^{a}$ & 261 & 1296 & 16.8 & & & 1 \\
\hline Education & $<6$ & 477 & 1807 & 20.9 & 33.75 & $0.0001^{b}$ & $2.16(1.67-2.81)$ \\
\hline $\begin{array}{l}\text { of head of } \\
\text { household }\end{array}$ & $\geq 6^{a}$ & 74 & 609 & 10.8 & & & \\
\hline
\end{tabular}

F: Fisher test OR: Odds Ratio Cl: confidence interval

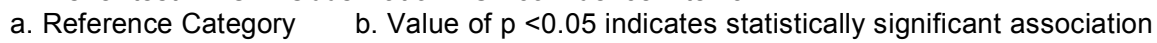

those presenting the greatest prevalence of stunted growth; the lowest corresponded to Medellín, Valle de Aburrá, Southeast, and Magdalena Medio. When assessing the magnitude of the stunted growth in the different sub-regions, it was noted that children belonging to the sub-regions of the North and Urabá have approximately twice the chance of experiencing the event than those living in Medellín. It should be stressed that for Bajo Cauca, the opportunity is tripled (Table 1).

When exploring the association of stunted growth with some demographic characteristics, it was found that girls, children below 1 to 5 years of age, and children from homes whose heads of household were younger than 30 years of age had a greater opportunity of experiencing the event (Table 1).

For the association of stunted growth with the socioeconomic characteristics studied, it was found that children living in rural areas, in homes with more than four members, with more than two children younger than 7 years of age, and poor per Unsatisfied Basic Needs(UNB) had greater probabilities of having stunted growth (Table 2).

On the association of stunted growth with dietary characteristics, we could determine that the minors living in homes with availability ofless than 30 different food items, with energetic insufficiency, and with 
Table 2

Distribution of stunted growth according to socioeconomic characteristics of children under 11 years of age and their homes. Antioquia, 2004

\begin{tabular}{|c|c|c|c|c|c|c|c|}
\hline \multirow[t]{2}{*}{ Variable } & \multirow[t]{2}{*}{ Category } & \multicolumn{2}{|c|}{ Stunted growth } & \multirow{2}{*}{$\begin{array}{c}\% \text { of Stunted } \\
\text { growth }\end{array}$} & \multirow[t]{2}{*}{$\mathbf{F}$} & \multirow[t]{2}{*}{$\mathbf{p}$} & \multirow[t]{2}{*}{ OR (CI 95\%) } \\
\hline & & Yes & No & & & & \\
\hline \multirow{3}{*}{$\begin{array}{l}\text { Area of } \\
\text { residence }\end{array}$} & Urban $^{\mathrm{a}}$ & 239 & 1214 & 16.4 & 9.23 & $0.0024^{b}$ & $1.34(1.11-1.62)$ \\
\hline & Rural & 312 & 1202 & 20.6 & & & \\
\hline & Extensive $^{a}$ & 209 & 995 & 17.4 & 2.57 & 0.0527 & 1 \\
\hline \multirow{3}{*}{$\begin{array}{l}\text { Typology of } \\
\text { home }\end{array}$} & NUM & 45 & 198 & 18.5 & & & $1.22(0.86-1.75)$ \\
\hline & Biparental & 259 & 1123 & 18.7 & & & $1.13(0.92-1.38)$ \\
\hline & NUF or Mixed & 38 & 100 & 27.5 & & & $1.77(1.17-2.69)$ \\
\hline \multirow{5}{*}{$\begin{array}{l}\text { Number of } \\
\text { members } \\
\text { Number of } \\
\text { children }<7 \\
\text { years }\end{array}$} & $<5^{\mathrm{a}}$ & 103 & 741 & 12.2 & 28.51 & $0.0001^{b}$ & 1.89 (1.49-2.38) \\
\hline & $\geq 5$ & 448 & 1675 & 21.1 & & & \\
\hline & $\overline{0}^{\mathrm{a}}$ & 48 & 341 & 12.3 & 21.21 & $0.0001^{\mathrm{b}}$ & 1 \\
\hline & $1-2$ & 337 & 1636 & 17.1 & & & $1.43(1.03-1.98)$ \\
\hline & $>2$ & 166 & 439 & 27.4 & & & $2.68(1.88-3.82)$ \\
\hline Poverty per & Yes & 437 & 1523 & 22.3 & 55.12 & $0.0001^{b}$ & $2.34(1.87-2.92)$ \\
\hline UBN & $\mathrm{No}^{\mathrm{a}}$ & 114 & 893 & 11.3 & & & \\
\hline
\end{tabular}

F: Fisher test OR: Odds Ratio Cl: confidence interval a. Reference category b. Value of $p<0.05$ indicates statistically significant association

NUM: Nucleated single-parental mother family NUF: Nucleated single-parental father family

perception of dietary insecurity had greater probability of having stunted growth (Table 3).

Determination of demographic, socioeconomic, and alimentary factors associated to stunted growth in children below 11 years of age. In the exploration, the model suggests that of the variables available, the ones best explaining stunted growth are: sub-region, gender and age of the child, age and schooling of the head of the household, the number of people in the home, the number of children below 7 years of age, poverty per unsatisfied basic needs (UBN), the number of different foods available in the home, production of food from crops or animal breeding. In addition to the aforementioned, an interaction term was found between gender and the age of the child (Table 4).

\section{DISCUSSION}

As shown by the results of the study, there are differences in the opportunity of presenting stunted growth according to the sub-region of the department where the children below 11 years of age are living. And, as observed in the model, these differences at the regional level coexist with other differences observed in the homes. Likewise, in a study on inequities in health in Colombia, Flóre $z^{3}$ also found an effect of the region in the development of stunted growth in children below 5 years of age.

Based on the results of the model, in the sub-regions of Bajo Cauca, North, Urabá, and Northeast the opportunity for stunted growth in minors is greater in comparison with Medellín. As acknowledged by some researchers, these regions share precarious socioeconomic conditions ${ }^{4,5}$.

As a biological variable, the child's gender was related to stunted growth. This has also been related in other research; however, the results are contradictory. Herrán et al. ${ }^{6}$, found that the male sex is a risk factor for stunting, thus is the case in other studies ${ }^{7,8}$. Nevertheless, other research ${ }^{9,10}$, like this one, shows that women have a greater probability for stunting than men. This finding suggests the need to explore and delve deeper into the cultural patterns that could be generating differential treatment towards girls during their first years of life.

For the department, we found stunted growth at $18.6 \%$ in children below 11 years of age in which the 
Table 3

Distribution of stunted growth according to alimentary characteristics of children below 11 years of age and their homes. Antioquia, 2004

\begin{tabular}{|c|c|c|c|c|c|c|c|}
\hline \multirow[t]{2}{*}{ Variable } & \multirow[t]{2}{*}{ Category } & \multicolumn{2}{|c|}{ Stunted growth } & \multirow{2}{*}{$\begin{array}{c}\% \text { of Stunted } \\
\text { growth }\end{array}$} & \multirow[t]{2}{*}{$\mathbf{F}$} & \multirow[t]{2}{*}{$\mathbf{p}$} & \multirow[t]{2}{*}{ OR (Cl 95\%) } \\
\hline & & Yes & No & & & & \\
\hline \multirow{2}{*}{$\begin{array}{l}\text { Number of } \\
\text { different foods }\end{array}$} & $<30$ & 342 & 1168 & 22.6 & 31.12 & $0.0001^{b}$ & $1.73(1.43-2.10)$ \\
\hline & $\geq 30^{\mathrm{a}}$ & 209 & 1248 & 14.3 & & & \\
\hline \multirow{3}{*}{$\begin{array}{l}\text { Food } \\
\text { production in } \\
\text { the home }\end{array}$} & $Y_{e s}^{a}$ & 211 & 1015 & 17.2 & 1.20 & 0.2731 & $1.12(0.92-1.36)$ \\
\hline & No & 340 & 1401 & 19.5 & & & \\
\hline & & 358 & 1411 & 20.2 & 9.12 & $0.0026^{b}$ & $1.36(1.11-1.66)$ \\
\hline \multirow{2}{*}{$\begin{array}{l}\text { Energetic } \\
\text { insufficiency }\end{array}$} & Yes & 193 & 1005 & 16.1 & & & \\
\hline & $\mathrm{No}^{\mathrm{a}}$ & 493 & 1946 & 20.2 & 22.18 & $0.0001^{b}$ & $2.01(1.50-2.69)$ \\
\hline \multirow{2}{*}{$\begin{array}{l}\text { Perception of } \\
\text { dietary } \\
\text { insecurity }\end{array}$} & Yes & 58 & 470 & 11.0 & & & \\
\hline & $\mathrm{No}^{\mathrm{a}}$ & & & & & & \\
\hline
\end{tabular}

F: Fisher test OR: Odds Ratio Cl: confidence interval a. Reference category

b. Value of $p<0.05$ indicates statistically significant association

prevalence increases with age. Through this study, we noted that those younger than one year of age had a lower probability of stunted growth than those 1-4 years of age or 5-10 years of age. In 2005, the nation established a prevalence of chronic malnutrition of $12.0 \%$ in children below 5 years of age and of $12.6 \%$ for those between 5 and 9 years of age; for Antioquia the figures were $11.4 \%$ and $11.1 \%$, respectively. This contrasts with only $6 \%$ stunted growth in children younger than one year of age for the nation ${ }^{8}$. Hence, this study shows a more acute situation than the studies mentioned. Additionally, the fact that the opportunity for stunting increases with age, suggests that stunted growth is the result of an accumulative process of socioeconomic privations. This finding is, furthermore, worrisome because, by stunted growth being a basically irreversible alteration, the height and health conditions of future generations are being compromised.

The heads of household were mostly 40 years old or more. Only $15.8 \%$ were younger than 30 years of age. Also, it was found that children from homes with heads of household who were below 30 years of age had $50 \%$ greater probability of stunted growth. This may possibly be indicating that in homes with young heads of household there may be greater labor instability, homes in the starting stage, or in expansion with very few possibilities of other contributors ${ }^{11}$. Furthermore, it has been shown that there is lesser probability of falling into poverty levels for elderly heads of household ${ }^{12}$. All this is related to the possibilities of providing resources for the necessary food and the rearing of the minors.

Schooling is an indicator of the individual's competitiveness and of his/her human capital ${ }^{12}$, in this sense; it contributes to improving employment possibilities, better income, and better family care guidelines. Therein, the greater number of years of schooling by the head of the household, the lower the opportunity for stunted growth; this finding is similar to that of Herrán et al. ${ }^{6}$

In the homes studied, an average of $5.3 \pm 2$ members were found, whereas National Survey on Demographics and Health ${ }^{13}$, reported an average size of 4.1 members for Colombia. The average size of the homes has direct repercussions on the dietary and nutritional security of its members: homes with lower numbers of individuals have greater possibilities of attaining quality and quantity of the required diet, better opportunities of health care and self care, and lower risk of overcrowding, among others.

Just as this study reveals that as the number of children below 7 years of age increases, the opportunity for stunted growth will be greater, other studies have reported this same finding ${ }^{6,14}$. A greater proportion of children younger than 7 years of age in the home represents a greater economic load and a lower possibility of guaranteeing an 
Table 4

Model of generalized equations estimation (GEE)

\begin{tabular}{|c|c|c|c|c|c|c|}
\hline Variable & Coef. & $\begin{array}{l}\text { Standard } \\
\text { error }\end{array}$ & DF & $\mathbf{T}$ & $\mathbf{p}$ & OR (Cl 95\%) \\
\hline Intercept & -5.671 & 0.5648 & 2.576 & -10 & $0.0001^{a}$ & \\
\hline Sub-region (Medellín) & 0 & & & & & 1 \\
\hline Sub-region (Valle de Aburrá) & 0.2273 & 0.2772 & 501 & 0.82 & 0.4126 & $1.26(0.73-2.16)$ \\
\hline Sub-region (East) & 0.4938 & 0.2560 & 534 & 1.93 & 0.0542 & $1.64(0.99-2.71)$ \\
\hline Sub-region (Southeast) & 0.1411 & 0.2665 & 534 & 0.53 & 0.5967 & $1.15(0.68-1.94)$ \\
\hline Sub-region (West) & 0.4719 & 0.2724 & 543 & 1.73 & 0.0837 & $1.60(0.94-2.74)$ \\
\hline Sub-region (North) & 0.6127 & 0.2445 & 580 & 2.51 & $0.0125^{a}$ & $1.85(1.14-2.98)$ \\
\hline Sub-region (Northeast) & 0.5603 & 0.2601 & 548 & 2.15 & $0.0316^{a}$ & $1.75(1.05-2.92)$ \\
\hline Sub-region (Magdalena Medio) & 0.2172 & 0.2735 & 545 & 0.79 & 0.4274 & $1.24(0.73-2.13)$ \\
\hline Sub-region (Urabá) & 0.5617 & 0.2331 & 522 & 2.41 & $0.0163^{a}$ & $1.75(1.11-2.77)$ \\
\hline Sub-region (Bajo Cauca) & 0.8648 & 0.2267 & 492 & 3.81 & $0.0002^{a}$ & $2.37(1.52-3.71)$ \\
\hline Sex of child & 1.7746 & 0.5336 & 2.707 & 3.33 & $0.0009^{a}$ & $5.90(2.07-16.8)$ \\
\hline Age of child $(<1)$ & 0 & & & & & 1 \\
\hline Age of child (1-5) & 1.4341 & 0.4860 & 2.587 & 2.95 & $0.0032^{\mathrm{a}}$ & $2.64(1.53-4.56)$ \\
\hline Age of child $(6-10)$ & 2.0316 & 0.4842 & 2.596 & 4.20 & $0.0001^{a}$ & $2.92(1.68-5.07)$ \\
\hline Age of head of household $(>39)$ & 0 & & & & & 1 \\
\hline Age of head of household (30-39) & 0.2930 & 0.1153 & 2.786 & 2.54 & $0.0111^{a}$ & $1.34(1.07-1.68)$ \\
\hline Age of head of household $(<30)$ & 0.3994 & 0.1463 & 2.659 & 2.73 & $0.0064^{a}$ & $1.49(1.12-1.99)$ \\
\hline Education of head of household & 0.5724 & 0.1519 & 2.690 & 3.77 & $0.0002^{a}$ & $1.77(1.32-2.39)$ \\
\hline Number of individuals in the home & 0.3962 & 0.1380 & 2.867 & 2.87 & $0.0041^{a}$ & $1.49(1.13-1.95)$ \\
\hline Number $<7$ years $(0)$ & 0 & & & & & 1 \\
\hline Number $<7$ years $(1-2)$ & 0.2243 & 0.1850 & 2.849 & 1.21 & 0.2253 & $1.25(0.87-1.80)$ \\
\hline Number $<7$ years $(>2)$ & 0.5557 & 0.2142 & 2.859 & 2.59 & $0.0095^{\mathrm{a}}$ & $1.74(1.15-2.65)$ \\
\hline Poverty per UBN & 0.3383 & 0.1350 & 2.764 & 2.5 & $0.0123^{a}$ & $1.40(1.08-1.83)$ \\
\hline Number of different foods available & 0.2661 & 0.1074 & 2.798 & 2.48 & $0.0133^{a}$ & $1.31(1.06-1.61)$ \\
\hline Food production in the home & 0.3940 & 0.1082 & 2.461 & 3.64 & $0.0003^{a}$ & $1.48(1.20-1.83)$ \\
\hline Gender (female)* Age of child $(<1)$ & 0 & & & & & $5.90(2.07-16.8)$ \\
\hline Gender (female) ${ }^{*}$ Age of child (1-5) & -0.939 & 0.5535 & 2.711 & -1.70 & $0.0004^{a}$ & $2.31(1.73-3.08)$ \\
\hline Gender (female) ${ }^{*}$ Age of child $(6-10)$ & -1.946 & 0.5534 & 2.720 & -3.52 & 0.0899 & $0.84(0.63-1.12)$ \\
\hline
\end{tabular}

Akaike information criteria: $14787.60 \quad$ a. Value of $p<0.05$ indicates statistically significant association

adequate diet for these children. These resources are not solely economic but also in terms of time and attention for the minor ${ }^{15}$. Regarding poverty measured by Unsatisfied Basic Needs (UBN), there are great differences among what was found through the research $(56.4 \%)$ and the official reports for Antioquia that speak of $31 \%$ for the same year.

Although in this field there are methodological discussions on the limitations on how to measure poverty and its scope ${ }^{16,17}$, the relationship of stunted growth with poverty per UBN (understood as structural poverty $)^{18}$, implies that the approach to the problem should be more integral if looking to overcome the issue of malnutrition.

The diversity of food available in the home is an indicator of the dietary quality, and, furthermore, it could be a suitable predictor of the energetic sufficiency in the homes ${ }^{19}$. The variety of foods guarantees the 
adequate supply of micro and macronutrients, avoiding alterations like deficiencies or metabolic problems through excess. For this, it is necessary to not only consume foods from the groups, but to have a variety of foods within each group; nevertheless, it has been found that the availability of foods from all the food groups does not guarantee dietary security in the homes, given that a low variety may be available within each group or low availability per capita/day ${ }^{19}$. This research reveals that the production of foods is a factor that protects the against the appearance of stunted growth in children below 11 years of age, and this is then, adjusting for condition of poverty, what becomes an important fact within the framework of dietary sovereignty.

From the methodological point of view, it is relevant to highlight the importance of considering the correlated structure of the data when constructing an explicative model. Given that the original sampling was representative per sub-regions of the department, it may be considered that each of them functions as a cluster and, therefore, the observations could be correlated, i.e., there is no independence of the observations inasmuch as there are contextual factors that may equally influence upon the children within a same sub-region.

All the aforementioned permits evidencing the weight of the socioeconomic conditions and particularly of structural poverty in stunted growth, which is important to insist on the need for integral policies to overcome such. These policies should consider a broad perspective of dietary safety that includes stimulus to food production for self-consumption articulated to regional development policies that improve access to foods, health conditions, and housing. Within these, we suggest considering a componentaimed athomes with Youngheads of household (below 30 years of age), which seek to improve their formal education and labor preparation.

Conflict of interests. No conflicts of interest arose during the development of this research and in the publication of the results.

\section{REFERENCES}

1. Álvarez M, Benjumea M, Roldán P, Maya M, Martínez M, Montoya E. Perfil alimentario y nutricional de los hogares del departamento de Antioquia. Medellín: Universidad de Antioquia, Gobernación de Antioquia; 2005.

2. Restrepo M. Los indicadores antropométricos en la evaluación del estado nutricional. Estado nutricional y crecimiento físico. Medellín: Universidad de Antioquia; 2000. p. 127-58.
3. Flórez C. La equidad en el sector salud: una mirada de diez años. Documento de trabajo $\mathrm{N}^{\circ} 6$. Bogotá: Fundación Corona, Fundación FORD; 2002.

4. Aramburo C, Arango J, Vélez L. Urabá. Desarrollo regional: una tarea común universidad-región. Medellín: Universidad de Antioquia; 2000.

5. Arango M, Maya M, Bejarano O. Bajo Cauca. Desarrollo regional: una tarea común universidad-región. Medellín: Universidad de Antioquia; 2000.

6. Herrán O, Prada G. Nutrición y socioeconomía: un estudio en niños pobres. Perspct Nutr Hum. 2001; 5: 11-29.

7. Profamilia, Instituto Colombiano de Bienestar Familiar, USAID, Ministerio de la Protección Social. Encuesta nacional de demografía y salud 2005: salud sexual y reproductiva en Colombia. Bogotá: Profamilia; 2005. p. 266-86.

8. Instituto Colombiano de Bienestar Familiar. Encuesta nacional de la situación nutricional en Colombia. Bogotá: Profamilia, Instituto Nacional de Salud, Universidad de Antioquia, Organización Panamericana de la Salud, Instituto Colombiano de Bienestar Familiar; 2005. p. 69-120.

9. Sakisaka K, Wakai S, Kuroiwa C, Cuadra-Flores L, Kai I, Mercedes-Aragón M, et al. Nutritional status and associated factors in children aged 0-23 months in Granada, Nicaragua. Public Health. 2006; 120: 400-11.

10. Khuwaja S, Shah S. Prevalence and correlates of stunting among primary school children in rural areas of southern Pakistan. J Trop Pediatr. 2005; 51: $72-7$.

11. Arriagada I. Estructuras familiares, trabajo y bienestar en América Latina. Santiago de Chile: CEPAL; 2003.

12. Guevara D. Dinámica de la pobreza en Colombia: análisis de los ingresos de jefes de hogar urbano 1984-2003. Econ Desarr. (Colombia) 2005; 4: 76-108.

13. Profamilia, Instituto Colombiano de Bienestar Familiar, USAID, Ministerio de la Protección Social. Encuesta nacional de demografia y salud 2005: salud sexual y reproductiva en Colombia. Bogotá: Profamilia; 2005. p. 29-47.

14. Fisberg RM, Cardoso MR. Nutritional status and factors associated with stunting in children attending public daycare centers in the Municipality of São Paulo, Brazil. Cad Saude Publica. 2004; 20: 812-7.

15. Sereebutra P, Aliyu M, Jolly P. Sociodemographic and environmental predictors of childhood stunting in rural Guatemala. Nutr Res. 2006; 26: 65-70.

16. Comisión Económica para América Latina. Avances recientes en la reducción de la pobreza. Panorama social de América Latina 2005. Santiago de Chile: CEPAL, Naciones Unidas; 2006. p. 59-92.

17. Contraloría General de la República. El debate sobre el tamaño de la pobreza en Colombia. Econ Desarr. 2004; 303 : 97-106.

18. Lora E. Técnicas de medición económica. Metodología y aplicaciones en Colombia. $3^{\mathrm{a}}$ ed. Bogotá: Alfaomega Colombiana SA; 2005.

19. Álvarez M, Rosique J, Restrepo M. Seguridad alimentaria en los hogares de Acandi: la disponibilidad de los alimentos como indicador de suficiencia alimentaria. Rev Chil Nutr. 2004; 31: 318-29. 